1 | P a g

\title{
Health Situation of Elderly People at Slum Area in Sylhet City
}

\author{
Biback Das ${ }^{1}$
}

\begin{abstract}
:
The research is carried out to assess factor affecting the health condition of the elderly people in the slum areas in Sylhet City. This research was quantitative type. In Quantitative approach, primary data were collected and used from the randomly selected elderly people in the Sylhet City slum areas. The secondary data were collected from many articles, documents, newspaper, magazine etc. By analyzing the survey data, it is illustrated that the slum dwellers are deprived from the basic needs. Meanwhile, elderly people can't fulfill their medical treatment due to their financial condition because of their work incompatibility. This study identifies the factor affecting health condition such as financial condition, lack of knowledge about proper medical facilities, communication gap between the authority and patient, unemployment, and so on. These factors also affect their health situation. Many diseases like asthma, heart disease are occurred. This study also mentions about the livelihood of slum people are so poor in condition. Due to financial condition, aged people can't take their proper treatment and their family member can't afford it. This study also understands that the people from slum areas are getting concerned about their medical care. They are easily going to the hospital and take their service because of low pricing. On the other hand, people are meanwhile stopped their treatment of financial situation. This study finds the health situation of elderly people at slum areas in metropolitan city and their consciousness.
\end{abstract}

\section{Key-Words: Health situation, Health care facilities, Elderly people, Slum areas.}

\footnotetext{
${ }^{1}$ An undergraduate student, Department of Public Administration, Shahjalal University of Science and Technology, Sylhet-3114
} 
2 | P a g

\section{Introduction:}

Bangladesh has the third largest population in South Asia after India and Pakistan. According to BBS (2011) Bangladesh has an urban population of about $4,19,43,532$ or just over $28 \%$ of its total population. Moreover, the urban population has been growing very rapidly since the liberation in 1971 and at present 2.96\% annually (BBS 2011). Bangladesh is passing through technological, social, cultural and demographic transition. Consequently increase in awareness of health care among the people took place, which led to the improvement in the quality of health care facility. The older people are one of the most vulnerable and high-risk groups in terms of health and socio-economic status in the society today, especially slum areas. Health status of the older people is a major concern in Bangladesh. Bangladesh lacks medical facilities and infrastructure to meet the needs of the vast slum population not to speak of the older population. Older people suffer from cumulative effects of a lifetime of deprivation, entering old age in a poor state of health, and without savings or material assets. In the urban and rural areas majority of the elderly population suffered from weakness followed by eye sight, sleeping problem, Blood pressure body pain and pin in joint . in rural areas more older population suffers from eyesight, hearing and denture, weakness, sleepless, mobility, blood pressure, stiff joint, constipation, pain in join in back rheumatic (Amirun N. M., Haque M. E., Siddiqua N. M. R. and Haque M. I.2013). 4,966 slums and squatter clusters and roughly 34,20,521 slum dwellers (out of a population of 91,36,182) live in the Dhaka Metropolitan area alone (Mahbub et al. 2005). Studies on the effects of environmental factors on slum dweller's health in the context of Bangladesh are scarce. A few studies have been made on urban environmental health situation in the informal settlements (Salahuddin and Islam 1982, Hussain et al. 1999). Therefore, this study was undertaken to understand the health care practices of older people and to gather some information about their perceive health needs using the information and over of Sylhet City. On the other hand, unhealthy people are usually poor because they cannot work to earn a living. They are usually malnourished and susceptible to diseases and therefore unable to work either in the fields in rural areas or work in factories in the cities, and are therefore unable to obtain food, shelter, and clothing. Thus, they become poor, and because they are poor and they cannot obtain adequate healthcare and become unhealthy and sick and eventually they become poorer. We can describe this as a vicious cycle. Keeping in mind the above scenario the current study has set out two objectives: to analyze the socio-economic and health condition of the Sylhet City slum people and to know the opportunities and other difficulties regarding their life and livelihood. This paper identifies about their health status and their knowledge about health care facilities. Collecting data from the vulnerable people from slum areas in Sylhet city and describing about their current situation. The crucial focus of the study is to know the influential factors the health care situations of older people at slum area in Sylhet City. This paper is also identifying how challenges of health care situation of slum areas affect the care of the older people and understanding the health condition of older people in the slum areas of Sylhet City and, evaluating the health seeking behavior and treatment patterns, 
3 I P a g

\section{Statement of the Problem:}

As a global level, $50 \%$ of those living in urban areas in developing countries living substandard housing. While the rate of urbanization is $4 \%$ and the slum growth rate is $6 \%$. The urban areas have always been perceived as a hive of commercial and industrial activities, especially after the industrial revolution. This induced unprecedented rural urban migration which many urban areas were not able to cope with. This precipitated serious housing shortage with led to overcrowding and congestion. This caused the deterioration of houses, the associated infrastructure and services. The governments assumed a "laissez-faire" attitude to housing provision. As such many substandard house were built with inadequate facilities. People of slum areas, they are migrated from various areas all over the Bangladesh for seeking a better life. Meanwhile, when they are being unable to work due to their aged problems or may be affected many serious disease and then they become unemployed depending on their family. People in the slum areas, especially older people, can't get proper health services due to their financial situation, lack of awareness about taking health services if they haven't faced proper financial assistance. They are facing many obstacles to get proper medical services such as where from they get services, how do they get medical services etc. Slum areas in Sylhet City, there is an overcrowded place where live a lot of people within a small place. Due to overcrowding, Elder people and infant are easily affected by many disease such as diahorrhea, and many water polluted disease. Even though due to aged situation, they have faced many aged problem like physical weakness, heart disease, diabetic, and other old aged problems. On the other hand, lack of appropriate knowledge of health conditions of their cannot be understand so what's problems of them. For unawareness of their physical situation, they face many incurability disease like diabetic, heart disease, cancer etc. One of the major point is communication gap. they don't know where to get health care facilities by free or easily. Sometimes they have engaged with many quacks like kobiraj, saman etc. Many times, due to missing of proper treatment, the deterioration of their health situation is occurred. This paper mainly tries to identifies about their problem of taking medical care from their locality.

\section{Rationale of the Study:}

Health is one of the important human rights that strengthens the persistence of human being and help them to increase basic capabilities. It is considered the important aspect by which humans can escape premature mortality. The level of ill health reduces the amount and productivity of man. Therefore human health is to a great extent essential for human and social development. Particularly, elderly people of health condition in sylhet slum areas are very weak. But in slums the common factors are poverty, poor-quality households, over-crowding, concentration of lowincome people, skilled and unskilled manpower, limited health care service and unhealthy environment, awkward social structure etc. For these reasons health care situation of slum people are very poor, especially elderly people situation is most vulnerable. Sufficient research papers, articles are not available about the health care facilities and health condition of the slum elder 
4 | P a g

people in Bangladesh, especially about the elder people living in Sylhet slums. With the increase of people living in Sylhet city, the impact of urban living on human health is now a growing concern. The rapid growth of slum populations in Bangladesh is an increasing challenge for local health authorities and deserves intensive investigations. Slums have often been conceptualized as areas of concentrated poverty, which comprise a social cluster that engenders a distinct set of health problems. So, it is the utmost importance to ensure health services for these growing numbers of city dwellers, especially the poor. This neglected population of slum has become a major reservoir for a wide spectrum of health conditions that the formal health sector must deal with. People residing in slums face many problems like improper sanitation, unhygienic environmental conditions, social, economic, health, educational and cultural problems and many more. The basic problems inherent in slums are health hazards. Lack of basic amenities like safe drinking water, proper housing, drainage, and sheet disposal services; make slum population vulnerable to infections. The physical environment also causes problems. There is a serious shortage of knowledge about basic hygienic condition, such as garbage collection, and as a result surrounding areas become polluted with garbage. Drains are not covered or kept clear, and so stagnant water collects, forming a breeding ground for mosquitoes and increasing the danger of malaria and dengue fever. Lack of sufficient or sanitary toilet facilities heighten the risk of diseases such as diarrhoea, dysentery, typhoid or cholera that are spread through contaminated food and water.

The cramped conditions of the slums, number of people per home and close proximity to others enables disease to spread rapidly, whether by air, water, food or from person to person. Slum conditions pose many dangers to the inhabitants' health. Lack of education means that elder people are unaware of the health problems caused by unhealthy conditions, and do not know how to prevent the spread of disease. Poverty means that food is often scarce or lacking in nutrients and a high proportion of women are malnourished. Very few women receive vaccinations and so diseases which have been almost eradicated elsewhere can become fatal to them. When health problem becomes apparent, people are often reluctant to seek medical help due to the costs involved. They can be misled by the advice offered by local "quacks" - people who pose as doctors but have no medical training. Their incorrect diagnoses and unsuitable medication pose more damage than illnesses themselves. The slum elder people are marginalized due to the difficulty of accessing healthcare services and information. They do not have access to public health services and private health care service is very expensive. Therefore, we think it will serve as an important document about the health condition of slum elder people in the field of research and policy makers could take necessary initiatives to improve the health care facilities of elder people living in the slum areas.

\section{Literature Review:}

S. Mookherji and D. Bishai (2006) reveal that urban health systems in Bangladesh must work to improve access to care by the poor. Evidence from this study also shows that the urban poor view health care as both an investment in future productivity and as a consumption good; as 
5 | P a g

such, urban health policy should view pre-paid financing schemes as a practical strategy for caring for the urban poor.

Over the years, despite many constraining factors, Bangladesh has experienced a steady growth in GDP per capita from $\$ 762.8$ in 1995 to $\$ 862.1$ in 20015, to the latest high of $\$ 957.8$ (World Bank) while the standard deviation has continued to decline at a steady pace. With the development of infrastructure, rise of food security and off-farm/non-farm employment, and the increase of literacy rate, Bangladesh have been involved in a continually-progressive sectoral shift for decades, and the ultimate result of that has been a rapid growth of urbanization and increased demand for healthcare services in urban centers. The per capita generation of electricity has increased from $95.85 \mathrm{kwh}$ in 1999-00 to a whopping $213.12 \mathrm{kwh}$ in 2012-13, indicating a significant improvement of the countries basic infrastructure (SYB 2013).

According to FAO (2013), the prevalence of food inadequacy in Bangladesh has also come down from $41.2 \%$ in $1990-92$ to $26.3 \%$ in $2012-14$, indicating rise in food security, which may have led to the sectoral shift in employment, from agriculture to manufacture and service. The life expectancy at birth also increased from 59 in 1994 to 69 in 2011.

At present UPHCP can cover less than half of these groups (about 25 lacs). Remaining 35 percent (about 40 lacs) of the entire population of Dhaka have unmet need." Given this situation, it is safe to say that many slum-dwellers end up with lower healthcare than they had in rural areas before they migrated from there. But in the question of how much healthcare to provide to the slum-dwellers, this study warns about the ruralization effect of providing too much healthcare services the slum-dwellers. The paper by Lahiry et al. sheds some light about factors that work in determining the determinants of healthcare among slum-dwellers. Demand for healthcare among slum-dwellers depend not only their income, but also on other constrains that they face (S R Howlader).

As a densely populated temporary residential house built lawfully or unlawfully having no water supply, sanitation facilities or electricity supply. Most of these are one-roomed dwellings and extremely overcrowded (Mr Salahuddin and Ms Ishrat ).

The World Bank, defined a slum as a residential area where more than three hundred people live in one acre ( 0.405 hectors) of land. An average of more than three adults live in a single room. 46 per cent of these houses are one-roomed and the average size is 120 square feet. Ventilation, drinking water, electricity and sewerage facilities are absent in these houses. The result of this study indicated that a significantly higher percent of women living in slums came from country side, had a poorer status by household characteristics, had less access to mass media, and had less education than women not living in slums (Md Mobarak H Khan and Alexander Kraemer). Md. Rubel, From this report it is also clear that female slum dwellers have extremely limited opportunities for a decent lifestyle: they lack a foundation for healthy and fulfilling lives, and at the same time carry immense responsibilities.

This study found that continued neglect of ever-expanding urban slum populations in the world could inevitably lead to greater expenditure and diversion of health care resources to the management of end-stage complications of diseases that are preventable. A new approach to 
6 | P a g

health assessment and characterization of social-cluster determinants of health in urban slums is urgently needed( Divisions of Infectious Disease and Epidemiology, School of Public Health, University of California, Berkeley).

Due to the rapidly growing population in the incessantly growing urban slums, there has been an alarming rate of growth of non-communicable diseases in these slums. The inhospitable and almost unhygienic environment of these slums sometimes works as an accelerant to the spread of diseases. Bangladesh has witnessed remarkable progress over the last few decades in health and population indicators, significant disparities exist within urban areas, between slum and nonslum-dwellers (NIPORT 2015; Roy et al. 2014).

Healthcare services also there is an inadequacy of appropriate policy and structure as well as misallocation of resources when it comes to the urban centers. This is a major obstacle to healthcare seeking behavior for urban slum-dwellers. The health challenges are exacerbated by the absence of functional policies or institutional structures to assure coordination of basic urban health services (Osman, 2009).

Uddin et al. (2009) found in their study on the healthcare seeking behavior of street-dwellers in Dhaka city that, not only most squatters have little to no knowledge about the location where to seek out healthcare service, but they didn't even visit any doctor or provider when they were ill in the year prior to the study. They posited that, “...the survey data show that about half of the females and one- third of the males did not seek health care services during their episodes of illness.."

The review clearly shows that the economy of Bangladesh has been growing, poverty has been declining and social and health indicators have been improving. The rate of increase in urbanization both in size and population, has been increasing rapidly. So is the slums in the urban areas. The rate of growth of slums in Sylhet city is alarmingly high. The slum-dwellers are deprived of the basic amenities of life, especially health and education opportunities. Compared to the people in the rural areas, let alone those in the urban areas, the use of healthcare from the qualified sources in the urban slum is very low, and the situation regarding the healthcare use remains stagnant over time. The reasons for this remains both on the demand and supply side. However the available literature doesn't show the latest statistic about the proportion of people demanding healthcare from the various sources in the urban slums. Moreover, no study has so far identified the actual reasons for low demand for healthcare and for that matter low use of healthcare services based on adequate evidence. 
7 | P a g

\section{Conceptual Framework:}

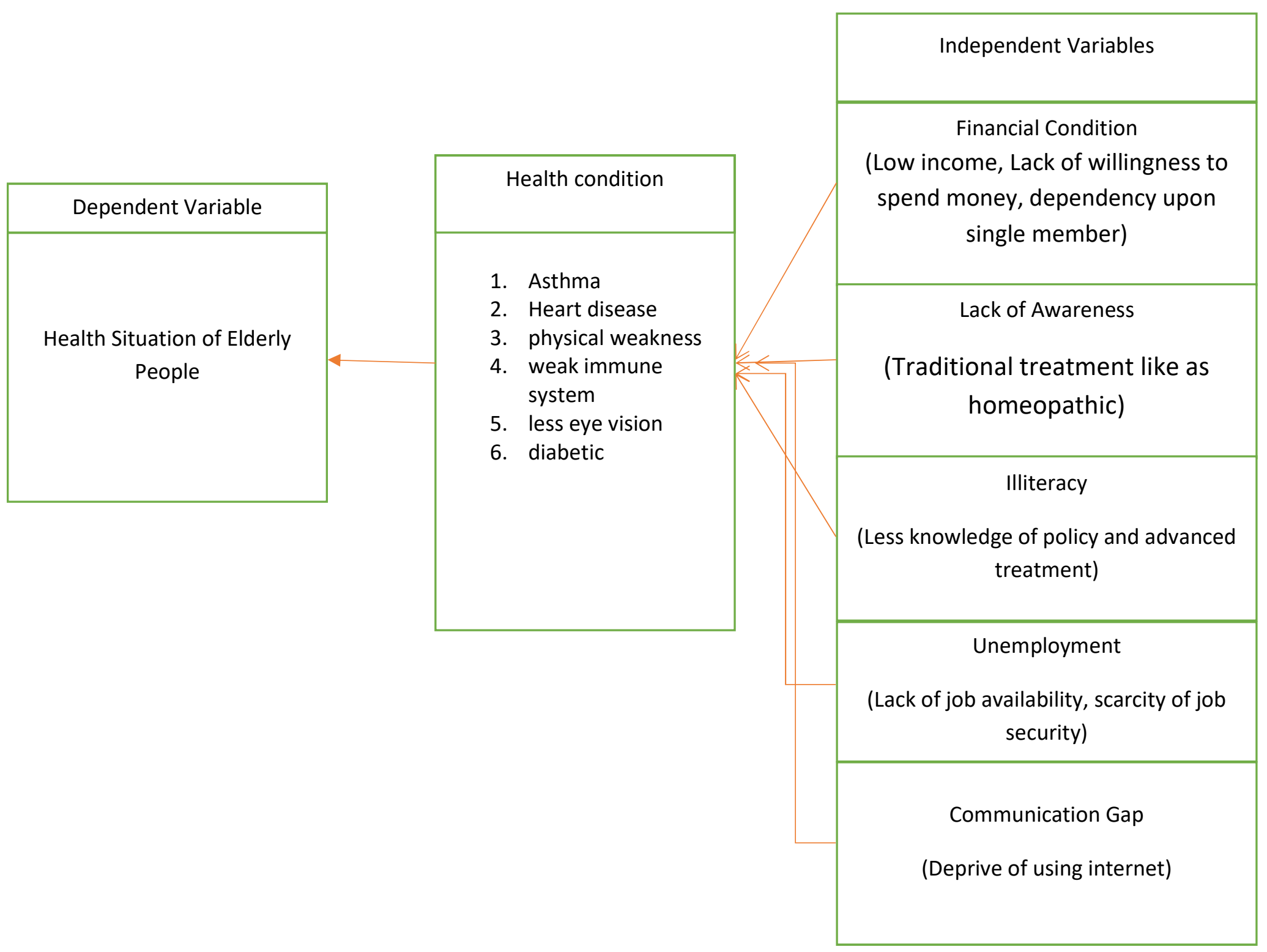

Fig (6-1) : Conceptual framework 
8 | P a g

The current status of health situation of elder people at slum areas in sylhet city depending on such factor such as financial condition, Lack of awareness, Illiteracy, Unemployment, and communication gap. If we suppose 'Current Health Situation' as dependent variable those factor work as independent variables. The study is confined to the analysis of the demand for healthcare for aged people in the slum areas in Sylhet city. The hypothesis is that the demand for healthcare from qualified providers among the slum dwellers is very low, even lower than in rural areas, due to certain constraints. The current status of elderly people's health situation in slum areas is depended on abovementioned factors. One factor can be changed the situation of elderly people in slum areas. Due to financial causes, they can't take proper health care. Sometimes, poverty may affect to take health care facilities from hospitals, clinic's etc. Basically, every family is depended on single income person, so maintaining all of household chores and others. It might seem very expensive to them for taking health care. Many simple disease like fever, diahorreah, etc, they have recourse to quack by little amount of money to take health care facilities. they take traditional treatment. Lacking of appropriate knowledge of where taking health facilities are existed.

\section{Research Methodology:}

In this research, descriptive and explanatory research has been used to achieve the objectives of the study. Descriptive research has been used because the main objective of the study is to explain the problems and challenges of getting modern health facilities of elder people at slum areas in Sylhet City according to their perceptions. Explanatory research is used because the study is explained the cause and effect relationship variable. This paper follows quantitative research approach has been used. Quantitative approach has been selected for empirical investigation via statistical or mathematical techniques which is used for well understanding the perception of the aged people perceptions on modern health the barriers and the data has been collected can be statistically represents. This study has been collected data from informants and has presented the real situation of counseling and health education services. In this paper, there have two types of data have been collected from both primary and secondary sources. Primary data has been collected from elderly people at slum areas in Sylhet City who are deprived of modern health facilities. A secondary source of data has been used to enrich this study. Secondary data has been collected from published e-books, journals, articles, reports of different organization which are related to the study. Data has been collected through the survey method. 
9| P a g

Because it is quantitative and mostly primary in character as well as helpful in getting more reliable and well organized information on particular problem. The study area has been covered with slum areas at entire Subid bazar, Pathantula, and Haoladar para Under Sylhet City Corporation. This area is selected because vulnerable aged (more than 50 years) people who are living in this area are mostly deprived of modern health facilities. Sylhet City Corporation has been selected by non- probability convenience sampling method because it is very easy to use and it also saves time and cost. Sample size is 25 in this study. All respondent are aged people living in Sylhet City Corporation under Sylhet District 
10 | P a g

\section{Data Presentation and Analysis}

\subsection{Age of the respondents:}

\begin{tabular}{|c|c|c|c|c|c|}
\hline & & Frequency & Percent & Valid Percent & $\begin{array}{l}\text { Cumulative } \\
\text { Percent }\end{array}$ \\
\hline \multirow[t]{13}{*}{ Valid } & 55 & 2 & 8.0 & 8.0 & 8.0 \\
\hline & 57 & 1 & 4.0 & 4.0 & 12.0 \\
\hline & 60 & 3 & 12.0 & 12.0 & 24.0 \\
\hline & 62 & 2 & 8.0 & 8.0 & 32.0 \\
\hline & 64 & 1 & 4.0 & 4.0 & 36.0 \\
\hline & 65 & 3 & 12.0 & 12.0 & 48.0 \\
\hline & 70 & 5 & 20.0 & 20.0 & 68.0 \\
\hline & 71 & 1 & 4.0 & 4.0 & 72.0 \\
\hline & 72 & 1 & 4.0 & 4.0 & 76.0 \\
\hline & 75 & 1 & 4.0 & 4.0 & 80.0 \\
\hline & 80 & 2 & 8.0 & 8.0 & 88.0 \\
\hline & 85 & 3 & 12.0 & 12.0 & 100.0 \\
\hline & Total & 25 & 100.0 & 100.0 & \\
\hline
\end{tabular}

Table-1.0 shows the majority of the respondents is from 55 to 85 years old that we collected data from the particular slum areas in Sylhet City. It reflects what types of people in this research study.

\subsection{Gender of the respondents:}

\begin{tabular}{|c|c|c|c|c|c|}
\hline & & Frequency & Percent & Valid Percent & $\begin{array}{l}\text { Cumulative } \\
\text { Percent }\end{array}$ \\
\hline \multirow[t]{3}{*}{ Valid } & Male & 9 & 36.0 & 36.0 & 36.0 \\
\hline & Female & 16 & 64.0 & 64.0 & 100.0 \\
\hline & Total & 25 & 100.0 & 100.0 & \\
\hline
\end{tabular}

Table-2.0 illustrates that most of the respondents are female (64\%) is 16 and the rest of the respondents are male(36\%). In this research, participation of women is significant. 
11 | P a g

3.0 Occupation of the respondents:

\begin{tabular}{|c|c|c|c|c|c|}
\hline & & Frequency & Percent & Valid Percent & $\begin{array}{l}\text { Cumulative } \\
\text { Percent }\end{array}$ \\
\hline \multirow[t]{12}{*}{ Valid } & Breakage Business & 1 & 4.0 & 4.0 & 4.0 \\
\hline & Business & 1 & 4.0 & 4.0 & 8.0 \\
\hline & Chef & 1 & 4.0 & 4.0 & 12.0 \\
\hline & Chef Occasional & 1 & 4.0 & 4.0 & 16.0 \\
\hline & Day Labourer & 3 & 12.0 & 12.0 & 28.0 \\
\hline & Driver & 1 & 4.0 & 4.0 & 32.0 \\
\hline & Householder & 7 & 28.0 & 28.0 & 60.0 \\
\hline & HouseWife & 4 & 16.0 & 16.0 & 76.0 \\
\hline & Not work Yet & 4 & 16.0 & 16.0 & 92.0 \\
\hline & Rickshaw Puller & 1 & 4.0 & 4.0 & 96.0 \\
\hline & Small Business & 1 & 4.0 & 4.0 & 100.0 \\
\hline & Total & 25 & 100.0 & 100.0 & \\
\hline
\end{tabular}

Table-3.0 indicates that most of the respondents were householder(28\%) when they were capable to do the work. It reflects what were of their profession when they were young at age. They had different form of profession. Some of them did more than one jobs for lead a better life.

\subsection{Serious Problem of the respondents:}

\begin{tabular}{|c|c|c|c|c|c|}
\hline & & Frequency & Percent & Valid Percent & $\begin{array}{l}\text { Cumulative } \\
\text { Percent }\end{array}$ \\
\hline \multirow[t]{3}{*}{ Valid } & Yes & 18 & 72.0 & 72.0 & 72.0 \\
\hline & No & 7 & 28.0 & 28.0 & 100.0 \\
\hline & Total & 25 & 100.0 & 100.0 & \\
\hline
\end{tabular}

Table-4.0 shows that the majority of the respondents now-a-days are facing serious problem that is $72 \%$ from survey especially they have been facing their aged problems. 
12 | P a g

5.0 Current_Health_Situation of the respondents:

\begin{tabular}{|l|l|l|l|l|}
\hline & Frequency & Percent & Valid Percent & $\begin{array}{l}\text { Cumulative } \\
\text { Percent }\end{array}$ \\
\hline Valid Aged Problem & 10 & 40.0 & 40.0 & 40.0 \\
Albino & 1 & 4.0 & 4.0 & 44.0 \\
Asthma & 5 & 20.0 & 20.0 & 64.0 \\
Asthma/T.B/Kidney & 1 & 4.0 & 4.0 & 68.0 \\
Diabetic/ Kidney & 1 & 4.0 & 4.0 & 72.0 \\
Disease & 2 & 8.0 & 8.0 & 80.0 \\
Heart Disease & 1 & 4.0 & 4.0 & 84.0 \\
Itching & 1 & 4.0 & 4.0 & 88.0 \\
Mental Illness & 1 & 4.0 & 4.0 & 92.0 \\
Paralysis & 2 & 8.0 & 8.0 & 100.0 \\
WellConditioned & 25 & 100.0 & 100.0 & \\
Total & & &
\end{tabular}

Table-5.0 refers that the majority of the respondents are suffering aged problem (40\%). It portrays of their current status of health. Facing of asthma is also significant because of their living place is unhygienic.

\subsection{Earning Member}

\begin{tabular}{|c|l|l|l|l|}
\hline & & & & Cumulative \\
& Frequency & Percent & Valid Percent & Percent \\
\hline Valid 1 & 15 & 60.0 & 60.0 & 60.0 \\
2 & 7 & 28.0 & 28.0 & 88.0 \\
3 & 1 & 4.0 & 4.0 & 92.0 \\
4 & 2 & 8.0 & 8.0 & 100.0 \\
Total & 25 & 100.0 & 100.0 & \\
\hline
\end{tabular}

Table-6.0 mentions from the respondents have minimum one earning member $(60 \%)$ at their family. 
13 | P a g

\subsection{Type Of Treatment}

\begin{tabular}{|c|l|l|l|l|}
\hline & Frequency & Percent & Valid Percent & $\begin{array}{l}\text { Cumulative } \\
\text { Percent }\end{array}$ \\
\hline Valid allopathic & 24 & 96.0 & 96.0 & 96.0 \\
$\begin{array}{c}\text { Traditional } \\
\text { Quack }\end{array}$ & 1 & 4.0 & 4.0 & 100.0 \\
Total & 25 & 100.0 & 100.0 & \\
\hline
\end{tabular}

Table-7.0 shows that most of the respondents are taking allopathic type of treatment that is $96 \%$ of the respondents. It understands us they are turned into modern health care.

\subsection{Visiting to Doctor}

\begin{tabular}{|c|c|c|c|c|c|}
\hline & & Frequency & Percent & Valid Percent & $\begin{array}{l}\text { Cumulative } \\
\text { Percent }\end{array}$ \\
\hline \multirow[t]{3}{*}{ Valid } & Yes & 12 & 48.0 & 48.0 & 48.0 \\
\hline & No & 13 & 52.0 & 52.0 & 100.0 \\
\hline & Total & 25 & 100.0 & 100.0 & \\
\hline
\end{tabular}

Table- 8.0 portrays the respondents are not going to the doctor easily. $52 \%$ of the respondents are not going to the doctor while $48 \%$ to visit to the doctor's chamber or somewhere else. Some of respondents are not going to doctor's chamber because of a little distance of medical. The rest of respondent among who have not enough financial assistance to take a check up.

\section{0 place's hygiene}

\begin{tabular}{|r|l|l|l|l|}
\hline & & & & $\begin{array}{l}\text { Cumulative } \\
\text { Percent }\end{array}$ \\
\hline Valid Yes & 18 & 72.0 & 72.0 & 72.0 \\
No & 7 & 28.0 & 28.0 & 100.0 \\
Total & 25 & 100.0 & 100.0 & \\
\hline
\end{tabular}

Table-9.0 illustrates that most of the respondent's(72\%) living place is hygiene. They are concerned about hygiene's. 
14 | P a g

10.0 Incurable Disease

\begin{tabular}{|c|c|c|c|c|c|}
\hline & & Frequency & Percent & Valid Percent & $\begin{array}{l}\text { Cumulative } \\
\text { Percent }\end{array}$ \\
\hline \multirow[t]{5}{*}{ Valid } & Heart Disease & 4 & 16.0 & 16.0 & 16.0 \\
\hline & Diabetic & 1 & 4.0 & 4.0 & 20.0 \\
\hline & Other & 1 & 4.0 & 4.0 & 24.0 \\
\hline & No & 19 & 76.0 & 76.0 & 100.0 \\
\hline & Total & 25 & 100.0 & 100.0 & \\
\hline
\end{tabular}

Table-10.0 illustrates that most of the respondents have not incurable disease $(76 \%)$.

\subsection{Curable Disease}

\begin{tabular}{|c|c|c|c|c|c|}
\hline & & Frequency & Percent & Valid Percent & $\begin{array}{l}\text { Cumulative } \\
\text { Percent }\end{array}$ \\
\hline \multirow[t]{6}{*}{ Valid } & Fever & 8 & 32.0 & 32.0 & 32.0 \\
\hline & Cough & 1 & 4.0 & 4.0 & 36.0 \\
\hline & Asthma & 6 & 24.0 & 24.0 & 60.0 \\
\hline & Other & 3 & 12.0 & 12.0 & 72.0 \\
\hline & No & 7 & 28.0 & 28.0 & 100.0 \\
\hline & Total & 25 & 100.0 & 100.0 & \\
\hline
\end{tabular}

Table-11.0 indicates the recent of the time, some of the respondents are suffering from fever that is $32 \%$ from the respondents.

\subsection{When Sick to seek Medical Care}

\begin{tabular}{|c|c|c|c|c|c|}
\hline & & Frequency & Percent & Valid Percent & $\begin{array}{l}\text { Cumulative } \\
\text { Percent }\end{array}$ \\
\hline \multirow[t]{3}{*}{ Valid } & Yes & 17 & 68.0 & 68.0 & 68.0 \\
\hline & No & 8 & 32.0 & 32.0 & 100.0 \\
\hline & Total & 25 & 100.0 & 100.0 & \\
\hline
\end{tabular}


15 | P a g

Table-12.0 illustrates that due to their sickness, the respondents are seeking medical care is $68 \%$. That is appreciable.

13.0 Type Of Medical Care

\begin{tabular}{|l|l|l|l|l|}
\hline & & & & $\begin{array}{l}\text { Cumulative } \\
\text { Percent }\end{array}$ \\
\hline Valid A Doctor's & 8 & Frequency & Percent & Valid Percent \\
Chamber & & 32.0 & 32.0 & 32.0 \\
Hospital's & 13 & 52.0 & 52.0 & 84.0 \\
Traditional Quack's & 4 & 16.0 & 16.0 & 100.0 \\
Total & 25 & 100.0 & 100.0 & \\
\hline
\end{tabular}

Table-13.0 mentions from the respondents, most of them are going to hospital's (52\%) to check up their health situation.

\subsection{Due To Financial Condition}

\begin{tabular}{|c|c|c|c|c|c|}
\hline & & Frequency & Percent & Valid Percent & $\begin{array}{l}\text { Cumulative } \\
\text { Percent }\end{array}$ \\
\hline \multirow[t]{3}{*}{ Valid } & Yes & 15 & 60.0 & 60.0 & 60.0 \\
\hline & No & 10 & 40.0 & 40.0 & 100.0 \\
\hline & Total & 25 & 100.0 & 100.0 & \\
\hline
\end{tabular}

Table-14.0 indicates that due to financial condition, they have to stop their treatment facilities that is told us $60 \%$ of the respondents.

\subsection{Medical Payment Bills}

\begin{tabular}{|c|c|c|c|c|c|}
\hline & & Frequency & Percent & Valid Percent & $\begin{array}{l}\text { Cumulative } \\
\text { Percent }\end{array}$ \\
\hline \multirow[t]{3}{*}{ Valid } & $\begin{array}{l}\text { Major } \\
\text { Impact }\end{array}$ & 17 & 68.0 & 68.0 & 68.0 \\
\hline & $\begin{array}{l}\text { Minor } \\
\text { Impact }\end{array}$ & 8 & 32.0 & 32.0 & 100.0 \\
\hline & Total & 25 & 100.0 & 100.0 & \\
\hline
\end{tabular}

Table-15.0 mentions us that to pay their medical treatment bills have faced major impact (68\%). 
16 | P a g

16.0 Negotiating Lower Price

\begin{tabular}{|c|c|c|c|c|c|}
\hline & & Frequency & Percent & Valid Percent & $\begin{array}{l}\text { Cumulative } \\
\text { Percent }\end{array}$ \\
\hline \multirow[t]{3}{*}{ Valid } & $\begin{array}{l}\text { Yes have } \\
\text { negotiated }\end{array}$ & 7 & 28.0 & 28.0 & 28.0 \\
\hline & No have not & 18 & 72.0 & 72.0 & 100.0 \\
\hline & Total & 25 & 100.0 & 100.0 & \\
\hline
\end{tabular}

Table-16.0 illustrates the majority of the respondents cannot negotiate to curb their treatment bill that is $72 \%$ from the respondents.

\subsection{Medical Expenditure}

\begin{tabular}{|c|c|c|c|c|c|}
\hline & & Frequency & Percent & Valid Percent & $\begin{array}{l}\text { Cumulative } \\
\text { Percent }\end{array}$ \\
\hline \multirow[t]{16}{*}{ Valid } & 0 & 7 & 28.0 & 28.0 & 28.0 \\
\hline & 100 & 1 & 4.0 & 4.0 & 32.0 \\
\hline & 150 & 1 & 4.0 & 4.0 & 36.0 \\
\hline & 200 & 1 & 4.0 & 4.0 & 40.0 \\
\hline & 250 & 1 & 4.0 & 4.0 & 44.0 \\
\hline & 500 & 2 & 8.0 & 8.0 & 52.0 \\
\hline & 600 & 2 & 8.0 & 8.0 & 60.0 \\
\hline & 1000 & 1 & 4.0 & 4.0 & 64.0 \\
\hline & 1200 & 1 & 4.0 & 4.0 & 68.0 \\
\hline & 1250 & 1 & 4.0 & 4.0 & 72.0 \\
\hline & 1300 & 1 & 4.0 & 4.0 & 76.0 \\
\hline & 1500 & 1 & 4.0 & 4.0 & 80.0 \\
\hline & 2000 & 3 & 12.0 & 12.0 & 92.0 \\
\hline & 2500 & 1 & 4.0 & 4.0 & 96.0 \\
\hline & 6000 & 1 & 4.0 & 4.0 & 100.0 \\
\hline & Total & 25 & 100.0 & 100.0 & \\
\hline
\end{tabular}


17 | P a g

Table-17.0 portrays that due to financial situation most of the respondents can't take their proper medicine that is $28 \%$. They cannot afford the amount of money.

\subsection{Financial Situation Get Favored}

\begin{tabular}{|c|c|c|c|c|c|}
\hline & & Frequency & Percent & Valid Percent & $\begin{array}{l}\text { Cumulative } \\
\text { Percent }\end{array}$ \\
\hline \multirow[t]{3}{*}{ Valid } & Yes & 5 & 20.0 & 20.0 & 20.0 \\
\hline & No & 20 & 80.0 & 80.0 & 100.0 \\
\hline & Total & 25 & 100.0 & 100.0 & \\
\hline
\end{tabular}

Table-18.0 show that most of the majority (80\%) can't any privilege to reduce their medical treatment bills. Some of respondents have closed relations with the employees of different medical colleges, clinics etc for what they can get financial help from them. 
18 | P a g

\section{Findings of the study:}

This study analyses the health situation of the elderly people in Sylhet City slum areas. Primary data are used and collected from the elderly people of Sylhet slum areas. After the analyzing of the data are getting many points about the factors those are influenced the health situation of aged people in Sylhet City slum areas. This study portrays the health condition of people especially aged people in slum areas how do they live there, what type of treatment they take, how about aware of government initiatives about the health care, how much spend to their health condition etc. This study, basically, conducts the people whose age range in more than 50 years old and also lives in a slum under the Sylhet City Corporation whose are seemed as vulnerable. This study depicts that the current health condition of respondents. There are almost half of the respondents are suffered various aged problem such as general weakness, less eye vision, hand shaking, pressure and so on. They have also affected many serious problem like heart disease, diabetic, asthma etc. Aged people's family have minimum earning member with low income that's why they can't afford the treatment paying bills. In sometimes, the medical care facilities have to stop when they are unable to pay medical bill. This study also finds that the elder people getting aware about their health situation. Nowadays, they are going to take their medical care at the nearby hospital's. Recent, most of the respondents have checked up at their local doctor's chamber, hospital's etc. By contrast, the consciousnesses about health, day by day, are increasing but financial condition falls major impact to continue their treatment. Another point is found from this study that make the lowering price of treatment is depended on the relationship between stuffs of the hospitals and somewhere else. Due to deprivation, they can't continue their medical treatment.

In an essence, this study illustrates the health situation of the elderly people in slum areas in Sylhet City and trying to relate with many variables that directly or indirectly affect the health condition of the ager people. 


\section{Conclusion:}

People from slum areas they are migrated from various part of Bangladesh due to urbanization. Slum life means a sub-human life being that deprived from fundamental constitutional rights. From the observations, opinion of the respondents, NGO workers, Govt. workers, local and Government representatives and previous data, it is clear that the health situation of the elderly people are affected various type of sickness such general weakness, eye vision, heart disease, diabetic etc. Because of financial condition, they can't continue their medical care but they are aware about their health condition. They are not doing like before. Most of them are taking allopathic treatment and checking up their body within a particular time. The socio-economic and infrastructural conditions were not well in the Sylhet City slum areas. Low level of income, unemployment, communication gap, lack of awareness also affects the health situation of the aged people in slum areas. This study tries to identify their problems and causes of caring their health care facilities. Our respondents are above 50years old. Some of them are still working but most of the parts of respondents are not capable of doing their jobs at survey time. They are not facing a significant amount of many serious problem like heart disease, diabetic, etc. But among the respondents, they have faced their aged problems. They take their health care of their nearby medical college hospitals, clinics, doctor's chamber etc. after completing our survey and assessing these we come to a point that they are being more conscious than before (when i read more relevant literatures). It seems they have more information about that. But there have more ill messages that they can't continue their treatment due to their financial insolvency. Overall, it is a good news that they are getting more aware of their health. They are not engaging with local quacks, traditional quacks, etc. 
20 | P a g

\section{References:}

Addressing Health of the Urban Poor in South-East Asia Region: Challenges and Opportunities.

(2011). World Health Organization.

Ahmed, S.M., Hossain, M.A. \& Chowdhury, M.R. (2009). Informal sector providers in Bangladesh: how equipped are they to provide rational health care? Health Policy and Planning $24,467-478$.

Amirun N. M., Haque M. E., Siddiqua N. M. R. and Haque M. I., Social Status of Elderly People in Health Perspective: A Comparison of Rural and Urban Area: OSR Journal Of Humanities And Social Science $\begin{array}{lllllll}\text { (IOSR-JHSS) Volume } & 18, & \text { Issue } & 6, & \text { PP. } & 83-94 & \text { (2013). }\end{array}$

Asiatic Society of Bangladesh. 2002. Banglapedia: The National Encyclopedia. Dhaka: The Asiatic Society of Bangladesh.

Bangladesh Demographic and Health Survey (2014). Key Indicators. NIPORT.

Bangladesh Demographic and Health Survey (2011). NIPORT.

BBS. 2015. Preliminary Report on Census of Slum Areas and Floating Population. Bangladesh Bureau of Statistics.

Health Economics Unit (HEU) of MoHFW and World Health Organization (WHO), 2015, Health Care Seeking Behavior of Slum-Dwellers in Dhaka City Results of a Household Survey.

Helal uz Zaman, A.K.M., Khan, M.T.A. \& Islam, M.J. (2010). Urbanization in Bangladesh: Present status and policy implications. ASA University Review, 4 (2)

Hossain, M.A., M. Moniruzzaman and M.A. Islam. 2010. Urban Environmental Health in Bangladesh Slum: A Comparative Study of Two Metropolitan Cities. J. Sci. Foundation 8(1\&2): 67-76.

Howlader, S R. Financing of Urban Primary Health Care in Bangladesh: Important Issues and A Framework for Analysis and Policy Formulation. (2011)

Latif Binte Mahmuda, Irin Anjuman and Ferdaus Jannatul , 2016, SOCIO-ECONOMIC AND HEALTH STATUS OF SLUM DWELLERS OF THE KALYANPUR SLUM IN DHAKA CITY, Bangladesh J. Sci. Res. 29(1): 73-83.

Kothari, C. R. 1990. Research Methodology, 2nd Edition, New Age International (P) Limited, India. p. 179.

Mahbub, A.Q.M., G. Angeles, P. Lance, N.I. Nazim. 2005. Centre for Urban Studies: Slum of Urban Bangladesh: Mapping and Census 2005.

The Daily New Age. 27-05-2005. Dhaka: Bangladesh

The Daily Prothom-alo. 13-10-2005. Dhaka: Banglades 